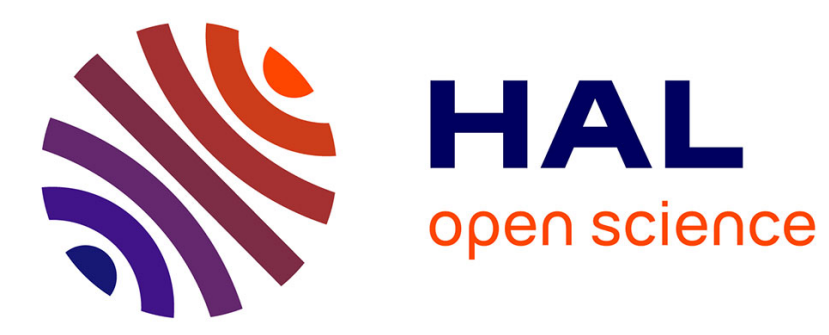

\title{
D'Alembert's Mathematical Correspondence: Beyond the Formal Description of Networks
}

\author{
Irène Passeron
}

\section{To cite this version:}

Irène Passeron. D'Alembert's Mathematical Correspondence: Beyond the Formal Description of Networks. Mathematical Correspondences and Critical Editions, pp.69-83, 2018, 10.1007/978-3-31973577-1_4. hal-02377948

\section{HAL Id: hal-02377948 \\ https://hal.science/hal-02377948}

Submitted on 13 Nov 2020

HAL is a multi-disciplinary open access archive for the deposit and dissemination of scientific research documents, whether they are published or not. The documents may come from teaching and research institutions in France or abroad, or from public or private research centers.
L'archive ouverte pluridisciplinaire HAL, est destinée au dépôt et à la diffusion de documents scientifiques de niveau recherche, publiés ou non, émanant des établissements d'enseignement et de recherche français ou étrangers, des laboratoires publics ou privés. 


\title{
D'Alembert's Mathematical Correspondence: Beyond the Formal Description of Networks
}

\author{
Irène Passeron
}

Abstract

D'Alembert (1717-1783) corresponded with some of the greatest mathemati- 6 cians of his time, Leonhard Euler, Gabriel Cramer, and Joseph Louis Lagrange. 7 This correspondence sheds light on the scientific controversies and epistemolog- 8 ical issues of the day. It also clarifies the organization of the academic world in 9 the middle of the eighteenth century, despite its lacks and losses. It allows us 10 to determine the precise various statuses of a "letter," from the most public to 11 the very private. We will question the relevance of a network epistolary repre- 12 sentation, by inserting mathematical problems into the context of other forms of 13 scientific communication: published treatises, academic reports, periodicals, and 14 the Encyclopédie (1751-1772), the main medium for D'Alembert's work and 15 for the Enlightenment. We will then focus on the relationships between Euler 16 and D'Alembert, inserted into the overlapping of Paris-Berlin antagonisms and 17 alliances.

Amongst the many different approaches that correspondences open us up to, two 19 lines will be put forward here: to question the meaning that sets down a graphical 20 representation of epistolary networks and, in parallel, to describe controversies by 21 interweaving the various levels of interpretation suggested by the analyses of other 22 written networks.

To speak of a network concerning mathematical correspondence may seem 24 both trivial and inadequate: the triviality of a graphical representation of this 25

\footnotetext{
I. Passeron $(\bowtie)$

CNRS, Sorbonne Université, Institut de Mathématiques de Jussieu-Paris Rive Gauche,

Paris Cedex 05, France

e-mail: irene.passeron@imj-prg.fr
} 
correspondence as a mapping of geographical networks, ${ }^{1}$ and the inadequacy 26 between a focus on this mode of expression and the diversity of the modes of both 27 exchanges and mathematical works.

By examining this tension, and by using the example of D'Alembert's correspon- 29 dence, which is better known today, ${ }^{2}$ we wish to clarify some of the parameters of 30 the notion of network and draw attention to what can be done so that it no longer 31 remains a static and inert material, but may, on the contrary, become a fertile ground 32 for further research and readings.

For the last 30 years, perceptive studies carried out on scientific correspondence 34 networks ${ }^{3}$ have enabled us to clarify, in different times and places, the three func- 35 tions of scientific correspondence: information (direct or indirect), legitimization of 36 the respective positions of speakers, and mediation with third parties. $\left.{ }^{4}\right) 37$

Despite keeping it as a model, the notion of a "network" goes further than the 38 simple graph of interconnections or even the structural frameworks of institutional 39 links (for example, academic) and the local spheres of exchange (family or high 40 society). Conversely, epistolary networks are often used to shed a contrasting light 41 on other known records, both academic and literary.

We must therefore question the very nature of an epistolary relationship and 43 the specific character of the semantic weight we attribute to it. Indeed, the notion 44 of an "epistolary network" only makes sense if we are capable of identifying the 45 parameters of the information, the impact, diffusion and variation of which we 46 want to measure. Therefore, we must possess an accurate, up-to-date and reliable 47 inventory and compare this network with other vectors of scientific exchange. ${ }^{5} \quad 48$

\footnotetext{
${ }^{1}$ The success of mapping correspondence lies in the fact that it provides a synthetic vision (on a map-modern or period, the correspondents being represented by localised dots and the letters by arrows) and, less often, a dynamic (in time), by placing these periodic exchanges within the context of other epistolary relations. It remains a challenge to map uncertainty and shortcomings.

${ }^{2}$ D'Alembert. CEuvres complètes, volume V/1, Inventaire analytique de la correspondance, Irène Passeron, in collaboration with Anne-Marie Chouillet and Jean-Daniel Candaux, 2009. Volume V/2, Correspondance 1741-1752, I. Passeron, in collaboration with Jean-Daniel Candaux, Alain Cernuschi, Frédéric Chambat, Michelle Chapront-Touzé, Christian Gilain, Alexandre Guilbaud, Guillaume Jouve, Françoise Launay, Marie-Laure Massot, François Prin, Christophe Schmit. Paris: CNRS Éditions, 2015. All of the information and references on the correspondence are taken from the collective works of the Groupe D'Alembert to which we refer. The Inventaire has benefited from the preliminary works undertaken by Martha Rezler, Gilles Maheu and John Pappas (especially J. Pappas 1989).

${ }^{3}$ See Beaurepaire et al. (2006) and Beaurepaire (2014).

${ }^{4}$ See Passeron et al. (2008).

${ }^{5}$ See A. Guilbaud's article in the present book and our attempt to provide a new way of browsing a mix of print and manuscript documents: http://dalembert.academie-sciences.fr/encyclopedie/ Dossier_Affaire_Tolomas/index.php
} 


\section{D'Alembert's Mathematical Correspondence as a Part of His Activity}

In order to discover which mathematical ideas and crucial scientific issues emerge 51 from D'Alembert's currently extant correspondence, we first of all need a broader 52 mapping of his activities and more precise biographical data than that revealed in 53 the letters, all written after the Minister's letter notifying him of his admission to 54 the Académie Royale des sciences when he was 23. ${ }^{6} 55$

Jean Le Rond, "newly born" when he was "found" on the steps of the church 56 St-Jean-Le-Rond on October 16th, 1717, was baptised after the name of the patron 57 saint of that very church. This was a name of which he was unaware for the part of 58 his youth spent with his wet nurse, ${ }^{7}$ his boarding school master and at the Collège 59 Mazarin, thinking at the time that his name was "d'Aremberg." 8 He obtained a 60 Master of Arts degree (maître ès arts) in 1735 under the name of Jean Le Rond, 61 and it is only before entering the Académie that he took, from then on, the name of 62 D'Alembert.

It is therefore Jean Le Rond D'Alembert, scholar with a complex identity, ${ }^{9} 64$ member of the most prestigious European Academies, ${ }^{10}$ who died in Paris on 65 October 29th, 1783, at the "Château du Louvre," in the apartment to which he was 66 entitled as Permanent Secretary of the Académie française.

As we must have knowledge of his scientific work (his treatises, academic 68 memoirs, participation in the Académie awards and his expert reports) and analyse 69 his publishing strategies, a third cartography is necessary, that of the social 70 connections his position in the enlightened world enabled him to establish at various 71 stages of his life.

We will discuss the context in which his discussions took place with the Basel 73 native Leonhard Euler ${ }^{11}$ (during Euler's time in St. Petersburg and Berlin) and the 74 Genevan Gabriel Cramer. ${ }^{12}$

\footnotetext{
${ }^{6}$ D'Alembert (2015), letter 41.01 from Maurepas to D'Alembert, May 13, 1741, p. 3-4.

${ }^{7}$ See F. Launay (2010).

${ }^{8}$ See F. Launay (2012).

${ }^{9}$ For this complexity, see I. Passeron (2009).

${ }^{10}$ Académie royale des sciences of Paris (1741), Academy of Berlin (1746), Royal Society of London (1748), Académie française (1754), Academy of Stockholm (1755), Institute of Bologna (1755), Imperial Academy of Saint Petersburg (1764), and many others throughout Europe.

${ }^{11}$ Leonhard Euler (1707-1783), princeps mathematicorum, was born in Basel. After his Saint Petersburg period, from 1727 to 1741, he took up a position at the Berlin Academy (1741), where he spent 35 years, before returning to Russia. During his very fruitful Berliner period, he was elected "associé étranger" of the Académie royale des sciences of Paris (1755) and won a great number of Academy Prizes. At least 40 letters were exchanged between both scholars.

${ }^{12}$ Gabriel Cramer (1704-1752) was a Genevan mathematician, not to be confused with Voltaire's publisher of the same name, Gabriel Cramer (1723-1793). We know that 25 letters were exchanged between Cramer and D'Alembert, of a very friendly nature, and we also have evidence that some are missing (D'Alembert 2015, p. xli).
} 
Finally, a mapping of the entanglement of the Republic of Letters and the 76 Republic of Sciences, which was still in its early stages, will enable us to identify 77 the part played by D'Alembert as he became renowned for solving mathematical 78 problems, or the forms of interactions existing between these resolutions and his 79 epistemological positions, expressed not only, for example, in the Encyclopédie, for 80 which he wrote the well-known Discours préliminaire, but also in his roughly 170081 articles on physics and mathematics. ${ }^{13}$

\section{The Characteristics of D'Alembert's Correspondence}

Now that these biographical points have been made, we can thereby evaluate 84 the significance of the extant correspondence of D'Alembert: 2300 letters sent or 85 received, none of which were from relatives (which is partly explained by the fact 86 that he had been abandoned and unrecognised, as well as being childless). However, 87 the definition of an epistolary corpus must be specified, because the very notion 88 of a "letter" has different facets, from the private letter, passed from hand to hand, 89 to the ostensible letter, ${ }^{14}$ or even the fake letter. ${ }^{15}$ Additionally, further evaluation 90 has led to further doubts: we counted up to 450 correspondents, but their identities 91 are sometimes uncertain, and may even mask multiple authors. Finally, in what is 92 probably the most difficult aspect to assess, one that is too often obscured by the 93 inventories, we need to determine the way in which these 2300 letters and 45094 interlocutors are representative of D'Alembert's correspondence, which implies that 95 we need to discover why and how letters have been kept, gathered, destroyed or 96 lost. ${ }^{16}$

Unlike others, D'Alembert did not keep an epistolary register, and we might 98 even say that he was not at all interested in doing so. What is obvious, however, is 99 that we only have a fraction of his correspondence, and that only exchanges with 100 correspondents who were, for various reasons, "privileged," such as Voltaire ${ }^{17}$ and 101

\footnotetext{
${ }^{13}$ For specific studies on D'Alembert's articles, see (online) the file 'D'Alembert et l'Encyclopédie" in RDE 21 (Chouillet 1996), Les branches du savoir dans l'Encyclopédie, RDE 40-41 (Leca-Tsiomis and Passeron 2006) and Gilain (2010), Guilbaud (2012), Schmit (2014).

${ }^{14}$ An "ostensible", or conspicuous letter is a letter written for the purpose of being shown or written knowing it would be shown (see D'Alembert 2015, Introduction, Privé versus Public, pp. xiv-xvii). Some of these, the most "ostensible" (from A43.10 to A83.01), are listed in D'Alembert (2009, Appendice, pp. 518-547). We have listed 2300 private and ostensible letters, excluding the fake and apocryphal ones.

${ }^{15}$ For fake and apocryphal letters, see D'Alembert (2009, p. xv and pp. 549-551) and D'Alembert (2015, Introduction, Lettres apocryphes, p. xvi).

${ }^{16}$ See D'Alembert (2015), Introduction, pp. xxi-xxiii.

${ }^{17}$ The correspondence with Voltaire begins in 1746 and comprises over 527 letters (known so far) until the death of the latter. See D'Alembert (2009), Introduction, pp. xxviii-xxix.
} 
Frederick II, ${ }^{18}$ or important figures within mathematics, such as Euler, Cramer and 102 Lagrange, ${ }^{19}$ have been rather well preserved. The density of these written records 103 must not, however, overshadow the many oral discussions he had with Diderot, ${ }^{20}{ }_{104}$ Condillac, ${ }^{21}$ Clairaut $^{22}$ and De Gua ${ }^{23}$ that were not followed up in writing. 105

D'Alembert often wrote for the purpose of cultivating intellectual and amicable 106 relations disrupted by distance (as was the case with Cramer after he left Paris in 107 1748), but also to follow academic activities, and even support them in cases of 108 priority disputes (as with Euler, whom he never met) or to clarify his reasoning 109 (with Lagrange).

Therefore, the only means to evaluate the way in which the letters are purported 111 to differ from academic relations and information transfers through periodicals 112 and prints is to compare their substance with what we learn from accounts of 113 institutional life and the various circulations of printed matter. 114

D'Alembert's extant correspondence is very unevenly distributed: 115

Apart from his nomination letter as "adjoint" at the Académie royale des sciences 116 in 1741, none of the letters written before 1746, the year he turned 29, have been 117 preserved. This gap is largely due to his status as a "bastard," nec pater nec res, ${ }^{24} 118$ and even more to the fact that he was childless. He had, however, more than one 119 adoptive family: his foster family, the Rousseaus, ${ }^{25}$ a family of glaziers with whom 120

\footnotetext{
${ }^{18}$ The correspondence with Frederick II (1712-1786, King of Prussia from 1740) begins in 1746 and comprises over 285 letters (known so far), until D'Alembert's death. See D'Alembert (2009), Introduction, p. xxvi-xxvii.

${ }^{19}$ Joseph Louis (Giuseppe Luigi) Lagrange (1736-1813), was a member of the Berlin Academy (1756) and of the Académie royale des sciences of Paris (1772). Their correspondence begins in 1759 and comprises over 172 letters, until D'Alembert's death. See D'Alembert (2009, Introduction, pp. xxviii-xxxi).

${ }^{20}$ In regard to his friend and colleague Denis Diderot (1713-1784), only one letter is known (D'Alembert 2009, letter 65.39). Like many Parisians, D'Alembert and Diderot ("Da and Di" as Voltaire said in his letter to Damilaville on April 8th, 1765) probably sent short letters to each other, all of which were lost.

${ }^{21}$ Also a friend from his early years, Etienne Bonnot de Condillac (1714-1780) had a great influence on D'Alembert's philosophy. No letters have been found, despite evidence of the existence of at least one (D'Alembert 2009, pp. xxxiv-xxxv).

${ }^{22}$ Alexis Claude Clairaut (1713-1765) was not a friend, but rather a stimulating rival, which is also a good circumstance under which to send and receive letters, although only a few letters are known of (D'Alembert 2009, letters 59.08, 59.09, 64.24, 64.25, 64.30 and ostensible letters A61.06, A62.05, A62.01, A62.06).

${ }^{23}$ Very little is known about the relationship between D'Alembert and the editor of the first project of the Encyclopédie, Jean Paul De Gua de Malves (1710-1786), except that they were close colleagues in the 1740s. No letters between the two academicians remain, an unsurprising fact, given that De Gua's correspondence and D'Alembert's correspondence of the 1740s have both disappeared.

24 "Neither father nor fortune": to understand how these words gave rise to the "Affaire" with Jesuit Father Tolomas, see the interface mentioned note 6 .

${ }^{25}$ D'Alembert's well known wet-nurse, "Mme Rousseau", was not very famous before the publication of F. Launay's study (Launay 2010): she was born Etiennette Gabrielle Ponthieu
} 
D'Alembert lived in Le Marais until he reached the age of 48, and the family 121 who served as his official guardians, the Destouches, ${ }^{26}$ from whom he received 122 a pension and with whom he was very close. The social status of the Rousseaus 123 and the fact that the members of the Destouches family were simply benevolent 124 guardians explains why D'Alembert did not write to them or, if he did, which was 125 probably the case with the Destouches family at least, why these exchanges were 126 not kept on either side. Furthermore, in 1746, he had already written two major 127 works, ${ }^{27}$ and there must have been exchanges, with Maupertuis, ${ }^{28}$ for instance, one 128 of his supporters at the Académie des sciences who had, at the time, left for Berlin. 129 Therefore, a number of D'Alembert's letters were not kept, and were most likely 130 discarded while he was still alive.

Besides, another imbalance is due to the fact that we have more letters sent by 132 D'Alembert than those received by him: the scholar kept fewer of his letters than 133 his correspondents did. ${ }^{29}$ What is more, D'Alembert's fame as Secretary of the 134 French Académie and as the "leading light" of French philosophers ${ }^{30}$ ensured the 135 preservation of certain of his letters from the eighteenth century to the present. 136

If we now examine the chronological distribution of the letters and correlate 137 it with their actual content, we notice a connection between their volume and the 138 scholar's official career. Indeed, it increases at the time of the Encyclopédie, except 139 during the mysterious 1759 "gap," 31 and reaches its peak during the activities of the 140 salon that he hosted together with Mlle de Lespinasse ${ }^{32}$; it then remains substantial, 141 thanks to his envied status as Permanent Secretary. 142

More specifically, during the early years, this correspondence was largely fuelled 143 by his exchanges with Euler. These stopped due to profound disagreements, and 144 even disputes, as was the case in 1751, and it was only in the 1760 s that the 145

(1682-1775), and when D'Alembert was born in 1717, she had taken the name "Mme Gerard" after her first marriage; she then took the name of her second husband, the glazier Rousseau, in 1726.

${ }^{26}$ Louis Camus Destouches (1667-1726), one of Fenelon's friends, was the first to be in charge of the young "Jean d'Aremberg". When he died, his brother Michel, and finally Michel's widow (in 1731), continued to provide for him (1200 livres tournois every year), guiding his first steps in the world (Launay 2012).

${ }^{27}$ Traité de dynamique (D'Alembert 1743), which contains the famous "D'Alembert's principle" and Traité de l'équilibre et du mouvement des fluides (D'Alembert 1744).

${ }^{28}$ Pierre Louis Moreau de Maupertuis (1698-1759), "the man who flattened the Earth", led an expedition to Lapland to determine the shape of the Earth (1736-1737), an issue at stake in the Newtonian-Cartesian controversy. He was then invited by Frederick the Great to be the first President of the Prussian Academy of Science (Terrall 2002).

${ }^{29}$ See D'Alembert (2015, Introduction, pp. xxi-xxiii).

${ }^{30}$ As Chevalier de Roubin said: "puisqu'avec raison on vous regarde comme le flambeau de l'europe, c'est vers vous qu'il faut aller pour etre éclairé”' (D'Alembert 2009, letter 73.84).

${ }^{31}$ See Fig. 1.

${ }^{32}$ Julie Jeanne Eleonore de Lespinasse (1732-1776), an illegitimate child like D'Alembert, became famous after she broke her friendship with Mme Du Deffand (1764) and set up her own "salon", "rue Saint-Dominique", where she lived with D'Alembert until her death. 


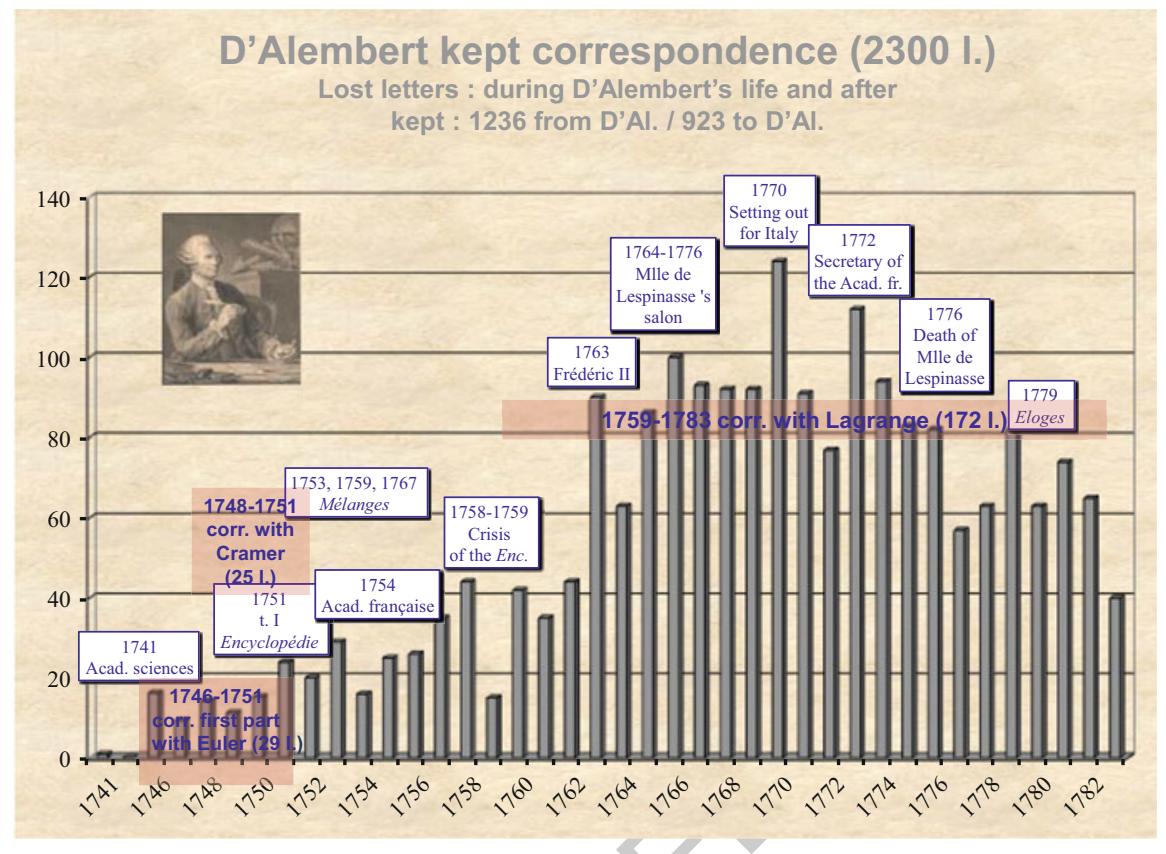

Fig. 1 Kept correspondence from and to D'Alembert

correspondence was resumed. The 30 letters exchanged between 1746 and 1751 (out 146 of 40 in total) are thus the most important, as they shed a completely new light on 147 the works of both scholars during that period: the fundamental theorem of algebra, 148 the vibrating strings, ${ }^{33}$ the theoretical crisis over Newton's theory of gravitation, 149 hydrodynamics, all elements that contributed to the genesis of the views of both 150 scholars, views they developed in their printed memoirs in a way that smooths over 151 the debates.

We are also lucky to possess, as a counterpoint, the discussions that both had 153 with the Genevan scholar Gabriel Cramer. Cramer's stay in Paris in 1747-1748 154 gave rise to a very close friendship between the two mathematicians, most likely via 155 the salons of Mme Geoffrin ${ }^{34}$ and Mme Du Deffand. ${ }^{35}$ But it was also a friendship 156 between philosophers: the theory of infinity, the theory of music, a large number of 157 issues brought them together and led to fruitful exchanges, the echoes of which can 158

\footnotetext{
${ }^{33}$ In particular, a recently discovered letter from Euler, D’Alembert (2015, pp. 39-47, letter 46.12). ${ }^{34}$ Mme Geoffrin, born Marie Thérèse Rodet (1699-1777), was linked with the Genevan patricians, the Saladins. Her "salon" was probably where D'Alembert met Cramer during his stay in Paris.

${ }^{35}$ Mme Du Deffand, born Marie de Vichy-Chamron (c. 1697-1780), was, at the beginning, a very dear friend of D'Alembert's, and supported him in 1754 in his election to the Académie française. Upset after her break with Mlle de Lespinasse, she was, at the same time, angry with D'Alembert and never forgave him for the choice he had made.
} 
be found even in the Discours préliminaire and in the articles of the Encyclopédie. ${ }^{36} 159$ Cramer's death in January 1752, of course, put an end to these exchanges. 160

It is only with Lagrange that D'Alembert was once more to have a genuine 161 scientific exchange, over a long period of time and with growing intensity, from 162 1759 until his death.

The figure represents what we call "private letters," even if there is no universal 164 definition of such letters. D'Alembert wrote at a period during which the channels 165 of expression were increasingly diversified through periodicals, but even though 166 the gradation of existing intermediaries makes it difficult, we can still distinguish, 167 in most cases, between the letters that were "ostensible" and those that were 168 "private.",37

It is not always easy to identify the sender or the recipient of a letter: it could be 170 an institution ${ }^{38}$ or it could also be more than one person. For instance, when Mlle 171 de Lespinasse dictated a letter to D'Alembert, which was destined for Condorcet, ${ }^{39}{ }_{172}$ the "secretary" was no longer "permanent" but "private," and he took the liberty of 173 including personal jokes. ${ }^{40}$ In addition, some people wrote letters that they knew, or 174 else pretended not to know, would be used publicly by, for example, being read in 175 the salons, being copied or even printed.

Finally, as far as some of the letters are concerned, we only know that they were 177 written to a woman or to an unidentified collaborator in the Encyclopédie, or we 178 have no certainty as to the identity of either the sender or the recipient. 179

We had to leave out all writings (notes, certificates or receipts) mistakenly 180 considered as letters by the previous publishers, in order to exclude, but nevertheless 181 report, literary frauds or sheer fabrications, often of slanderous intent. On the 182 other hand, the "Extraits des différentes Lettres de M. d'Alembert à M. de la 183

\footnotetext{
${ }^{36}$ For instance, the article "Courbe" of the Encyclopédie ou Dictionnaire raisonné des sciences, des arts et des métiers, written by D'Alembert, quotes and praises Cramer's book (Cramer 1750): "ouvrage très-complet, très-clair \& très-instructif, \& dans lequel on trouve d'ailleurs plusieurs méthodes nouvelles" (Encyclopédie, vol. IV, 1754, p. 388a).

${ }^{37}$ See note 15 .

${ }^{38} \mathrm{~A}$ fortiori if the sender or the recipient is the permanent secretary of an Academy, it is often impossible to draw a clear distinction between what falls under an individual word and what falls under an academic word.

${ }^{39}$ Marie Jean Antoine Nicolas de Caritat, marquis de Condorcet (1743-1794), was D'Alembert's spiritual son. Unfortunately, their correspondence was lost. See Nicolas Rieucau's contribution in the present book.

${ }^{40}$ Mlle de Lespinasse dictating, D’Alembert writing: "vous avez encore tort de faire de la géométrie comme un fou, de souper comme un ogre et de ne pas plus dormir qu'un lièvre. Vous croyez bien que ce n'est pas mon secrétaire qui dit cela"; "mon secrétaire ne sait jamais ni ce qu'il dit, ni ce qu'il fait—(pure bêtise de dire cela: cette pensée est du secrétaire)"; "il est très incommode de dicter à un homme aussi admirable que mon secrétaire, qui fait d'aussi beaux mémoires à l'Académie, ou qui est aussi maussade à la maison"; "mon revêche secrétaire veut bien écrire à mon bon Condorcet"; "mon secrétaire et moi, nous vous écrivons en commun"; "le secrétaire vous embrasse et trouve qu'en voilà assez. Ce mot est son cachet et vous y reconnaîtrez sa grâce enchanteresse." (D’Alembert 2009, letters 69.46; 69.50; 69.55; 71.77; 72.33; 74.43).
} 
Grange" (Mémoires de Turin, 1765), which we also had to eliminate from this 184 correspondence, although they are worthy of publication as part of D'Alembert's 185 works, were but a stratagem he came up with, in connivance with Lagrange, to 186 publish mathematical texts elsewhere than in the Paris or Berlin academic memoirs. 187

The great variety and quantity of documents that we possess demonstrate that the 188 boundaries between the public and the private spheres are blurred, and that they are 189 representative of the various positions occupied by D'Alembert: as co-director of the 190 Encyclopédie; member of the Académie royale des sciences; Permanent Secretary 191 of the Académie française; but also recipient, as well as sender, of epistles, and 192 therefore both a "public" and a private figure.

\section{The Characteristics of D'Alembert's Publications and Manuscripts}

D'Alembert's correspondence is closely linked to the printed word ${ }^{41}$ and to academic activity. ${ }^{42}$ Even the few purely amicable or social letters that have reached us, sometimes miraculously, bear witness to this connection. ${ }^{43}$ Indeed, the tumultuous news that they relate is closely connected to literary and political debates. ${ }^{44}$

\footnotetext{
${ }^{41}$ This fact illustrates the growing influence of the printing world, even over the growing culture of the private sphere (on this, see Chartier and Martin 1991). For instance, D'Alembert gets acquainted with Euler by sending him his works: "Monsieur de Maupertuis m'a remis tant Votre lettre que Vos ouvrages" (D'Alembert 2015, letter 46.12, p. 39). But, on the other hand, a book can also be linked to an acutely topical issue, when he writes to Cramer: "M. Diderot, mon intime ami, que vous connoissés de reputation, s'est avisé de donner au Public une lettre sur les aveugles, ou il y a d'excellentes choses sed non erat his locus", telling his friend living in quiet Geneva that Diderot has been imprisoned in La Bastille following the publication of the Lettre sur les aveugles à l'usage de ceux qui voyent, a controversial issue due to his atheistic materialism (D'Alembert 2015, letter 49.09, pp. 227-228).

${ }^{42}$ Almost nothing is known about the debates, if not disputes, which enlivened the academic sessions in Paris or Berlin, but allusions are numerous, for example, when D'Alembert blames Euler for his partiality when examining his paper proposed for the Berlin prize: "Je scai aussi par une voie tres sure qu'il s'est passé bien des vilainies sur ce sujet” (D'Alembert 2015, letter 51.15, pp. 348-349).

${ }^{43}$ In a short letter (a "billet" hand-delivered between addresses in Paris) written to his friend, la marquise de Crequÿ, (1714-1803) D'Alembert expresses this proximity in a witty remark: "Je m'amuse à vous ecrire, à condition que c'est pour vous seule, j' ay pourtant assez d'ouvrage: quatre epreuves à corriger, un avertissement a achever, l'Errata du second volume à composer, les Jesuites à batonner, les jansenistes à fustiger..." (D’Alembert 2015, letter 51.24, pp. 364-365).

${ }^{44}$ The letters give public information ["Comme j'allais fermer ma lettre il m'est arrivé trois prêtres [... ] Ils m'ont beaucoup parlé du livre de Buffon et de celuy de Montesquieu, que la Sorbonne veut condamner" (D'Alembert 2009, letter 53.07 to Mme de Crequÿ)] and unofficial information (“A propos de President, le Montesquieu m'a ecrit une assez jolie lettre. Il ne veut point de democratie et despotisme mais il est bien tenté de prendre l'article Goût. Vous ne vous en seriés jamais douté ny moy non plus.") (D'Alembert 2009, lettre 53.26 to Duché, about Montesquieu's contribution to the Encyclopédie).
} 


\begin{tabular}{|c|c|c|c|}
\hline Treatises & Académie des sciences & Académie française & Encyclopédie \\
\hline & 1741: « adjoint » & & \\
\hline \multicolumn{4}{|l|}{ 1743: Traité de dynamique } \\
\hline $\begin{array}{l}\text { 1746-1752: works on winds, } \\
\text { moon, precession, fluids }\end{array}$ & 1746: « associé » & & $\begin{array}{l}\text { 1751: vol. I } \\
\text { Discours préliminaire }\end{array}$ \\
\hline 1752 : Elémens de musique & & 1753 : Mélanges & $\begin{array}{l}1752: \text { vol. II } \\
1753: \text { vol. III }\end{array}$ \\
\hline \multirow[t]{3}{*}{ 1754-56 : Système du monde } & & 1754: member & $\begin{array}{l}1754 \text { : vol. IV } \\
1755 \text { : vol. V }\end{array}$ \\
\hline & $\begin{array}{l}\text { 1756: «pensionnaire } \\
\text { surnuméraire " }\end{array}$ & & $\begin{array}{l}1756: \text { vol. VI } \\
1757: \text { vol. VII }\end{array}$ \\
\hline & & 1759 : Mélanges + 2 vol. & 1759: condamnation \\
\hline \multirow[t]{5}{*}{$\begin{array}{l}\text { 1761: Opuscules, } \\
\text { t. I-II }\end{array}$} & & $\begin{array}{l}1762 \text { : Cath. II's proposition } \\
\text { from } 1763 \text { : Fréd. II }\end{array}$ & \\
\hline & 1765: «pensionnaire» & 1765-7 : Jésuites, Mél.+1 vol. & 1765: vol. VIII-XVII \\
\hline & 1769: « directeur » & & \\
\hline & & 1772: « secrétaire perpétuel » & \\
\hline & $\begin{array}{c}\text { 1773: Condorcet « secrétaire } \\
\text { perpétuel » }\end{array}$ & & 1776-7: Supplément \\
\hline $\begin{array}{c}\text { 1780: Opuscules, } \\
\text { t. VII-VIII }\end{array}$ & & 1779 : Eulogies & \\
\hline
\end{tabular}

Fig. 2 Bio-bibliographic landmarks

If we consider his printed works, we can divide them into four major categories, 200 which are punctuated with biographic landmarks and which differ in their dissemi- 201 nation and audience (Fig. 2). 202

The first is that of the great scientific treatises. Theses treatises, written between 203 1743 and 1756, are all centred around a theme: dynamics (1743), fluids (1744), 204 the general cause of winds (1746), the lunar theory (1747-1749), the precession 205 of equinoxes (1749), music (1752) or the world system (1754-1756); and they 206 involve key mathematical issues: partial differential equations of motion and 207 equilibrium, the fundamental theorem of algebra, complex numbers, series. Later 208 on, the Opuscules were published (nine volumes in total, although the last remains 209 unpublished) which comprise a collection of various memoirs and in which we find 210 further discussions on these subjects.

In the second category, we find the works related to his activities at the Académie 212 des sciences: the texts he published in his annual Mémoires, his expert reports and 213 his role as a member of the prize commission. ${ }^{45}$

The third category is linked to his literary activity, which gained momentum 215 throughout his life and was at its peak after his nomination as Permanent Secretary 216

\footnotetext{
${ }^{45}$ These internal texts will be published in volume III/11 "D'Alembert académicien des sciences" of D'Alembert. CEuvres complètes, along with the speeches read out on special sessions of the Paris Academy of Sciences.
} 
of the Académie française in 1772. Many of these works address issues relative to 217 language and its formalisation in the Dictionnaire de l'Académie française. He also 218 wrote numerous eulogies, ${ }^{46}$ which formed a kind of "catechism" of good scholarly 219 practice.

The fourth category, frequently interacting with the previous ones, is centred on 221 his writings for the Encyclopédie, ${ }^{47}$ essentially from 1746 to 1759 (the moment 222 when D'Alembert withdrew from the enterprise).

\section{$4 \quad$ D'Alembert, Euler and Cramer Between 1748 and 1752}

Having established this groundwork, we can describe more precisely how math- 225 ematical information was restored and circulated between D'Alembert, Euler and 226 Cramer from 1748 until 1752, just before and just after the publication of the first 227 volume of the Encyclopédie.

If we place these exchanges on a map of Europe, we notice that mathematical 229 correspondence (pure or mixed mathematics), which was the theatre of numerous 230 controversies between the years 1746 and 1752, revolves around two main inter- 231 locutors, and therefore two destinations. Apart from his subsequent correspondence 232 with Lagrange, it is during that period that D'Alembert's mathematical exchanges 233 intensify: with Euler in Berlin and with Cramer in Geneva. The intensity of these 234 exchanges enables us to estimate the number of letters that have been lost at 235 approximately 30, but the remaining 55 letters are still very instructive. 236

Apart from reading the correspondence with the secretary of the Berlin 237 Académie, Formey, having background knowledge of the correspondence of its 238 President, Maupertuis, would be desirable, as he played an important part in 239 D'Alembert's early career at the beginning of the $1740 \mathrm{~s} .{ }^{48}$ It is through him that 240 D'Alembert came into contact with the Berlin Académie of which he then became 241 a member, thanks to the prize he received for his Réflexions sur la cause générale 242 des vents in 1746 (the only one he ever received, because the one he applied for 243 next, the prize on resistance of fluids, caused his dispute with Euler). Unfortunately, 244 most of Maupertuis's correspondence has been destroyed, but the few elements that 245

\footnotetext{
${ }^{46}$ These eulogies contributed to his success, as he read a lot of them in the French Academy public sessions, such as the eulogy for Massillon read on August 25th, 1772, or the eulogy for Bossuet read in 1775: "cet endroit a été saisi avec transport par le public, qui a applaudi à enfoncer la salle", as reported by Julie de Lespinasse to Condorcet (Passeron 2009).

${ }^{47} \mathrm{He}$ wrote numerous articles in the Encyclopédie ou Dictionnaire raisonné des sciences des arts et des métiers about physics and mathematics, and the famous "Discours préliminaire", as well as controversial non- scientific articles: "Collège", on Jesuit education, and "Genève", on Genevan pastors' deism. For more details about these contributions, see the ENCCRE project: http://enccre. academie-sciences.fr/

${ }^{48}$ A letter found recently, from D'Alembert to Father Jacquier, shows that, from 1745 on, Maupertuis asked the French scholar to come to Berlin. See also D'Alembert (2015, Introduction, pp. lii-liii and lxxxi-lxxxii).
} 
remain enable us to see that, in 1752, the negotiations between D'Alembert and 246 Euler on whether or not the memoirs or rectifications should be published in Berlin 247 passed him, and to some extent Formey, by.

D'Alembert and Euler had indeed ceased to communicate by the end of 1751, 249 the former being sickened by what he thought were bad practices on the part of 250 the Berlin mathematician, the latter frightened by the encyclopaedist and showing 251 little interest in exchanging with him. ${ }^{49}$ It is obvious that the strong friendship, 252 if we can call it thus, between D'Alembert and Frederick II did not contribute to 253 making D'Alembert agreeable in the eyes of the right-minded and true believer 254 Euler. In the meantime, in Geneva, Cramer did his best to deal with these two great 255 mathematicians.

If we take into account all of the information provided by the bibliographical 257 analysis, the canvas of the mathematical controversies between D'Alembert and 258 Euler during these years appears to be a junction and an overlapping of various 259 antagonisms and alliances.

At first, their exchanges were connected to academic prizes, whether from Berlin 261 or from Paris. It is thanks to D'Alembert's vote that, in 1748, Euler ${ }^{50}$ won, amongst 262 many others, the prize related to Jupiter's satellites in Paris. At the time, the points 263 of friction between both scholars were not yet explicit. This mathematical exchange 264 takes its full meaning in the dual context of the French and Berlin academies, via 265 Maupertuis, ${ }^{51}$ and in D'Alembert's opposition to the French Court, which drew 266 him closer to Berlin as early as 1746.52 This rapprochement is illustrated by the 267 very flattering dedication of the Cause des vents to Frederick the Great, which 268 D'Alembert had carefully worked out in his letters to the Marquis d'Adhemar. ${ }^{53} 269$

In parallel, between 1747 and 1749 , the well-known ${ }^{54}$ controversy over the 270 movement of the lunar apsis was in full swing. There was no open rupture 271

\footnotetext{
${ }^{49}$ About the ideological differences and scientific focal points between D'Alembert (or Condorcet) and Euler, see Gilain (2013) and D'Alembert (2015, Introduction, § IV, VI and VIII).

${ }^{50}$ At this time, Euler was a well-known mathematician, a member of the Berlin Academy since 1741 and "commissaire" (member of the committee that awards the prizes). He competed prizes of the Académie des sciences, where D'Alembert was also "commissaire", and on the other side, D'Alembert competed Berlin prizes.

${ }^{51}$ Maupertuis was a member of the Académie des sciences from 1723 to 1746, when he left Paris for Berlin, to become President of the Berlin Academy. Frederick II subsequently requested of him that he recruit the best European scholars.

${ }^{52}$ D'Alembert thought he was treated better by Frederick II than by his own king. He was very proud to win the first prize given by the new Berlin Academy, in 1746, and quite angry to be underestimated in France.

${ }^{53}$ Antoine Honneste François, marquis d'Adhemar (c. 1710-1785), was a cavalry captain, friend of the encyclopedists, who left the army in 1752 to become grand-maitre at the court of Frederick II's sister, Wilhelmine, Margravine of Bayreuth.

${ }^{54}$ Thanks to the works of Michelle Chapront-Touzé, which made possible the publication of D'Alembert's Lunar theory: see D'Alembert (2002) and also D'Alembert (2006) for the important question of precession of equinoxes.
} 
(except vis-a-vis Buffon ${ }^{55}$ ), but rather a fruitful debate between D'Alembert, Euler 272 and Clairaut, although disputes over priority were being hatched. Many questions 273 of pure mathematics underlying the works on the general cause of winds (1746) and 274 on celestial mechanics were raised and discussed: the way to solve the so-called 275 "fundamental theorem of algebra," 56 which put Euler in opposition to D'Alembert, 276 the relevance of examples and counter-examples, up to the principle of the method 277 itself-algebraic for Euler, analytic for D'Alembert. There again, the epistolary 278 voice of the friend, Cramer, came as a counterpoint, and that of the rival, Clairaut, 279 expressed itself through the Mémoires de l'Académie. $\quad 280$

Nevertheless, the main reason for the breakdown between Euler and D'Alembert 281 was probably the award for the determination of the fluid resistance laws: as we can 282 see in the correspondence, D'Alembert was convinced that Euler was responsible, as 283 "commissaire" in Berlin, for many "villainies," which prevented him from receiving 284 the prize. 57

Finally, the publication at the end of 1750 of Cramer's work, Introduction 286 à l'analyse des lignes courbes algébriques, was used by D'Alembert to echo 287 and orchestrate his opposition to Euler. Indeed, D'Alembert thought that he had 288 discovered the mistake made by De Gua ${ }^{58}$ before Euler, when De Gua [?] affirmed, 289 in his work published in 1740, that no algebraic curve could have a cusp of the 290 second kind. D'Alembert also claimed to be the first to demonstrate analytically the 291 existence of such singular points. 292

Moreover, his change of position regarding De Gua, although he had written a 293 positive review of his work in 1740 , can also be understood in the context of the early 294 stages of the Encyclopédie. ${ }^{59}$ Indeed, De Gua managed the enterprise from June 295 1746 - at the time, it was just a project centered around translating the two volumes 296 of the Cyclopaedia - but in October 1747, the booksellers dismissed him, judging 297 that his work was insufficient, and so they signed a contract with D'Alembert and 298 Diderot, who thereafter became the editors of the Encyclopédie. ${ }^{60} 299$

These beginnings were already tumultuous: Diderot was at the Bastille and 300 Formey was claiming payment for the papers he had given to the enterprise, which 301 De Gua was taking time to pay. D’Alembert intervened in all of these developments, 302 and consolidated his status as an academician who could not be overlooked, despite 303 his unorthodox opinions, particularly in the eyes of Jesuits.

\footnotetext{
${ }^{55}$ At this time, the relations between the mathematician D'Alembert and the naturalist Buffon (1707-1788) were friendly, but not close.

${ }^{56}$ See D’Alembert (2007) and Christian Gilain's analysis.

${ }^{57}$ The affair began with the report of the prize in May 1750, and ended with D'Alembert's letter 51.15: see D’Alembert (2015, pp. cxvi-cxx).

${ }^{58}$ See n. 24.

${ }^{59}$ As D'Alembert tells Cramer: "c'est un homme qui se plaint de tout le monde, parce que tout le monde a à se plaindre de luy” (D’Alembert 2015, letter 51.02, p. 313).

${ }^{60}$ For the "prehistory" of the Encyclopédie, see Wilson (1985, pp. 73-82).
} 
It is to this type of reconstruction of the ideological landscape that the publication 305 of the Euvres complètes is dedicated. A reconstruction made possible by a detailed 306 analysis of a correspondence, which is at times incomplete, and that makes sense 307 only in light of the whole body of writings that inspired it.

\section{References}

Beaurepaire, Pierre-Yves, Jens Häseler, and Antony McKenna, eds. 2006. Réseaux de correspon- 311 dance à l'âge classique (XVIe-XVIIe siècle). Saint-Etienne: Publications de l'Université de 312 Saint-Etienne.

Beaurepaire, Pierre-Yves, ed. 2014. La Communication en Europe de l'âge classique au siècle des 314 Lumières. Paris: Belin.

Chartier, Roger, and Henri-Jean Martin. 1989-1991. Histoire de l'édition française, 2nd edition, 2. 316 Paris: Fayard et Cercle de la librairie.

Chouillet, Anne-Marie, ed. 1996. D’Alembert et l'Encyclopédie. Paris: Société Diderot 318 (Recherches sur Diderot et sur l'Encyclopédie 21). 319

Cramer, Gabriel. 1750. Introduction à l'analyse des lignes courbes algébriques. Genève: Frères 320 Cramer et Philibert.

D’Alembert, Jean Le Rond. 1743. Traité de dynamique. Paris: David l'aîné. 1758, 2nd edition. 322 Paris: David.

—. 1744. Traité de l'équilibre et du mouvement des fluides. Paris: David l'aîné. Vol. 1770. 324 Seconde éd ed. Paris: Briasson. -1746. Réflexions sur la cause générale des vents. 1747. Berlin: Haude \& Spener (published 326 in november 1746).

- 2002. CEuvres complètes. Série I. Vol. 6. Premiers textes de mécanique céleste (1747- 328 1749), ed. M. Chapront-Touzé. Paris: CNRS Editions. 329

- 2006. Euvres complètes. Série I. Vol. 7. Recherches sur la précession des équinoxes et 330 sur la nutation de l'axe de la terre dans le système newtonien, eds. M. Chapront-Touzé and J. 331 Souchay. Paris: CNRS Editions.

- 2007. Euvres complètes. Série I. Vol. I/4a. Textes de mathématiques pures 1745-1752, 333 ed. C. Gilain. Paris: CNRS Editions. 334

- 2009. CEuvres complètes. Série V. Vol. 1. Inventaire analytique de la correspondance 335 1741-1783, eds. I. Passeron, A.-M. Chouillet, and J.-D. Candaux. Paris: CNRS Editions. 336

- 2015. Euvres complètes. Série V. Vol. 2. Correspondance générale 1741-1752, eds. 337 I. Passeron, J.-D. Candaux, A. Cernuschi, F. Chambat, M. Chapront-Touzé, C. Gilain, A. 338 Guilbaud, G. Jouve, F. Launay, M.-L. Massot, F. Prin, and C. Schmit, Paris: CNRS Editions. 339 Gilain, Christian. 2010. La place de l'analyse dans la classification des mathématiques: de 340 l'Encyclopédie à la Méthodique. Recherches sur Diderot et sur l'Encyclopédie 45: 109-128. 341 2013. Sur l'expression "mathématiques des Lumières". In Raison et passions des 342 Lumières, eds. Simone Mazauric and Pierre-François Moreau, 213-226. Paris: L'Harmattan. 343 Guilbaud, Alexandre. 2012. À propos des relations entre savoirs théoriques et pratiques dans 344 l'Encyclopédie: le cas du problème de la résistance des fluides et de ses applications. Recherches 345 sur Diderot et sur l'Encyclopédie 47: 207-242. 346

Launay, Françoise. 2010. D'Alembert et la femme du vitrier Rousseau, Etiennette Gabrielle 347 Ponthieux (c. 1683-1775). Recherches sur Diderot et sur l'Encyclopédie 45: 100-106. 348

- 2012. Les identités de D’Alembert. Recherches sur Diderot et sur l'Encyclopédie 47: 349 243-289.

Leca-Tsiomis, Marie, and Irène Passeron. 2006. Les branches du savoir dans l'Encyclopédie. 351 Recherches sur Diderot et sur l'Encyclopédie 40-41: 7-13. 
Passeron, Irène, Siegfried Bodenmann, and René Sigrist. 2008. La République des sciences. Dix- 353 Huitième siècle 40. Paris: La Découverte.

Passeron, Irène. 2009. D’Alembert: construction d'une identité scientifique au XVIIIe siècle. 355 Jahrbuch für Europäische Wissenschaftskultur 4 (2008): 11-34.

Schmit, Christophe. 2014. Les articles de mécanique de l'Encyclopédie, ou D'Alembert lecteur de 357 Varignon. Recherches sur Diderot et sur l'Encyclopédie 47: 225-258.

Terrall, Mary. 2002. The Man Who Flattened the Earth. Maupertuis and the Sciences of the 359 Enlightenment. Chicago: The University of Chicago Press.

Wilson, Arthur Mc Candless. 1985. Diderot. New York: Oxford University Press (French trad. 361 Diderot. Sa vie est son ceuvre. Paris: Laffont Ramsay). 